\title{
Production of Lightweight Concrete Using Corncob Ash as Replacement of Cement in Concrete
}

\author{
Sintayehu Assefa, Mamaru Dessalegn \\ Department of Civil Engineering, Faculty of Civil \& Environmental Engineering, Jimma Institute of Technology, Jimma University, Jimma, \\ Ethiopia
}

Email address:

sintayehua9@gmail.com (S. Assefa),mam.wree@gmail.com (M. Dessalegn)

\section{To cite this article:}

Sintayehu Assefa, Mamaru Dessalegn. Production of Lightweight Concrete Using Corncob Ash as Replacement of Cement in Concrete. American Journal of Civil Engineering. Vol. 7, No. 1, 2019, pp. 17-20. doi: 10.11648/j.ajce.20190701.13

Received: February 11, 2019; Accepted: March 11, 2019; Published: March 25, 2019

\begin{abstract}
One of the biggest issues, all over the world is getting affordable house to the community. In developing countries, where it is difficult for most people to satisfy basic needs, construction of modern house is a big challenge. Different ways were tried by researchers and scholars to find alternative construction materials. One of this is replacing the costly construction material of cement with locally available material, especially with those considered as waste. Corncob is an agricultural waste, which is considered as one of binding materials. Very few researchers tried to use corncob ash as a means of producing lightweight concrete. So, this research was aimed to check whether corncob ash is used to produce lightweight concrete by replacing cement as a binding material or not. In order to reach on conclusion, corncob was collected from agricultural farmers and burned in furnace at a temperature of $850^{\circ} \mathrm{C}$. The burned ash powder was sieved in order to remove coarser material and replacement of cement was done by $5 \%, 10 \%, 15 \%, 20 \%, 25 \%, 30 \%$, and $35 \%$ with corncob ash. For each replacement, including control, 3 samples were prepared based on ASTM standards. After curing for 7 and 28 days in curing tank, the weight and compressive strength of samples were checked. Based on the experimental result, as the percentage of corncob ash increase, the weight of cubes decreased and 15\% and above corn cob ash replacement makes concrete cubes lightweight. The compressive strength was also decreasing as the amount of replacement increase. However, up to $15 \%$ replacement, compressive strength is found within the range of concrete grade requirement.
\end{abstract}

Keywords: Corn Cob Ash, Density of Concrete, Lightweight Concrete, Cement Replacement

\section{Introduction}

Shelter is one of the basic needs of human being. United Nations Center for Human Settlements estimates indicated that, more than half of the urban populations in developing countries live in life and health threatening conditions [1]. Unless dramatic and determined efforts are made on the housing front, trends and estimates point out that the situation is likely to become even worse. Studies show that, basic conventional building materials like cement and aggregates are becoming increasingly expensive due to high cost incurred in their processes, production and transportation [2]. The fast growth of industry, inflation of the market, and limitation of quality construction materials like sand and agregate in Ethiopia are the main reasons for its cost increase.

On the other hand, the production of concrete is not environmentally friendly, and therefore significant environmental advantages may be realized if alternate, environmentally sensitive materials are identified for use in concrete [3]. From the standpoint of natural resources using alternative solid waste material, as construction material is becoming global concern because, the cost of construction materials is increasing day by day due to high demand, scarcity of raw materials, and high price of energy [4]. The history of using alternative construction materials specially wastes is long and successful. The key factors to be considered when selecting alternative construction materials are: cost, availability of technology to implement, availability of material and attitude of community towards the materail [5]. Considering the above factors it is better to focus on waste materials and naturally available materials that has not been practiced. Cement is the essential component of concrete, when hydrated, binds the 
aggregates together to form the hard. Over $95 \%$ of the cement used in concrete throughout the world is Portland cement in its various forms [6]. It is by no means a simple material, and its complexities have an impact on the properties and behavior of concrete from mixing right through to the end of its life [6].

Lightweight concretes are preferable in many perspectives. In addition to their advantage of decreasing dead load of structure, they are economical, environmentally friendly, cellular, lightweight, structural materials that provide thermal and acoustic insulation as well as fire resistance [7]. Often lightweight concrete is produced by using lightweight aggregate. However, some researchers proposed materials having pozolanic property can be used to produce lightweight concrete. Some of them are applied and the results are promising. Study conducted by M. Nisnevich et al. [8] shows, using coal ash as replacement of cement makes concrete lightweight. Other materials like incenerator bottom ash [7], Sludge ash [9], Corn Cob ash [1] and the like are possible pozolanic materials that can be used for production of lightweight concrete.

As developing country, living with around $80 \%$ farmers, considering agricultural product as alternative construction material is best option. Bagasse, rise husk, rice straw, Banana stalks, bamboo, Corn cob and others are most commonly studied agricultural products as alternative pozolanic material. In Ethiopia, one of highly produced agricultural product is corn. The cob from this product is mostly considered as waste and its usage is not as such. Studies show that, it is one of good alternative cementing materials in concrete production [10].

\section{Materials and Methods}

Raw materials used for this study were Corncob, Natural Sand available around Jimma, Crushed Aggregate from crusher site, OPC type Cement from Dangote cement factory, and tap water.

\subsection{Corn Cob Ash}

Dry Corn Cob was collected from Horizon Plantation found around Gojeb near to Jimma. Corn cob was burned using incinerator at a temperature of $850^{\circ} \mathrm{C}$, to avoid formation of crystalline ash which is less reactive to lime. Burned powder was then sieved using sieve size of $7.4 \mu \mathrm{m}$. According to A. M. Neville [11], there is no simple relation between strength and cement particle size. So, particle size distribution analysis was neglected.

\subsection{Sand}

The sand used was first tested for silt content, it was found to be $4.95 \%$, which is below the $5 \%$ limit of Ethiopian standard [12]. Sieve analysis was done and fineness modulus is found to be 3.0, which is in the range of ASTM C33 standard 2.3 to 3.1 [13].

\subsection{Coarse Aggregates}

Coarse aggregate having a maximum size of $25 \mathrm{~mm}$ was collected from crusher site and checked for main aggregate properties.

Aggregate gradation was based on ASTM C33 standard 10 $\mathrm{Kg}$ sample, which was taken by quartering method and shacked on the mechanical shaver for $10 \mathrm{~min}$. The result of the analysis shows Gravel from the crusher site has a fineness modulus of 7.49. Unit weight of aggregate was found to be $1726.7 \mathrm{Kg} / \mathrm{m}^{3}$, which is in the range of normal weight aggregate according to ASTM standards [13]. Specific gravity and water absorption were determined using a balance with suitable apparatus. The splitter was used to sample coarse aggregate. Finally, $2 \mathrm{Kg}$ sample was taken from each type and soaked in water for $24 \mathrm{hr}$. After $24 \mathrm{hr}$, measurement was taken and sample was again measured in saturated surface dry (SSD) condition. The sample was then inserted into $105^{\circ} \mathrm{C}$ oven for 24 hours and then removed and cooled sample weight was taken. The summary of coarse aggregate properties is as shown in Table 1 below.

Table 1. Properties of Coarse Aggregate.

\begin{tabular}{|c|c|c|c|}
\hline No. & \multicolumn{2}{|l|}{ Test Description } & Crushed Rock \\
\hline 1 & \multicolumn{2}{|c|}{ Moisture Content (\%) } & 0.76 \\
\hline 2 & \multicolumn{2}{|c|}{ Unit weight Compacted $\left(\mathrm{Kg} / \mathrm{m}^{3}\right)$} & $1,726.7$ \\
\hline 3 & \multicolumn{2}{|c|}{ Absorption capacity (\%) } & 1.26 \\
\hline \multirow{3}{*}{4} & \multirow{3}{*}{ Specific gravity } & Bulk & 2.66 \\
\hline & & Bulk (SSD) & 2.70 \\
\hline & & Apparent & 2.75 \\
\hline
\end{tabular}

Based on collected data, mix design was done and cubic specimens were prepared for replacement of $0 \%, 5 \%, 10 \%$, $15 \%, 20 \%, 25 \%, 30 \%$ and $35 \%$ Corncob ash as replacement of cement. The mix design was done [4], trial percentage has been used for corrections on the amount of material. The design was done for the maximum aggregate size of $25 \mathrm{~mm}$, for C-25 concrete and slump value from $25 \mathrm{~mm}-50 \mathrm{~mm}$. After preparing specimens, samples were cured in a temperature controlled curing tank for 7 and 28 days according to ASTM Standard [14].

\section{Results}

\subsection{Workability of Concrete}

Before casting concrete, workability of fresh concrete was determined using slump test. This was done for all percentage of corncob ash replacement. As shown in the table 2 below, slump value was decreasing when percentage of corncob ash increased. This indicates, workability of fresh concrete decreases when the amount of corncob ash increase. This is mainly due to high water absorption capacity of corncob material. Even though the slump value is decreased as percentage of corn cob ash is increased, until the amount of percentage is became $20 \%$ the slump value is within the specified limit. Therefore, it is possible to replace the cement with $20 \%$ of corn cob ash. 
Table 2. Slump Test Result of Concrete.

\begin{tabular}{ll}
\hline \% of Corn Cob Ash & Slump value (mm) \\
\hline $0 \%$ & 32 \\
$5 \%$ & 29.5 \\
$10 \%$ & 28.1 \\
$15 \%$ & 26.7 \\
$20 \%$ & 25.5 \\
$25 \%$ & 23.4 \\
$30 \%$ & 21.2 \\
$35 \%$ & 19.0 \\
\hline
\end{tabular}

\subsection{Bulk Density of Concrete}

The main aim of this study was to check whether it is possible to produce lightweight concrete by replacing Portland cement with corncob ash or not. Samples were cured for 7 and 28 days and their weight is measured before compressive test was conducted. The samples have similar volume of $0.00157 \mathrm{~m}^{3}$, their mass was measured and the density is found to be decreasing when the amount of corn cob ash replacement increases as shown below in Figure 1.

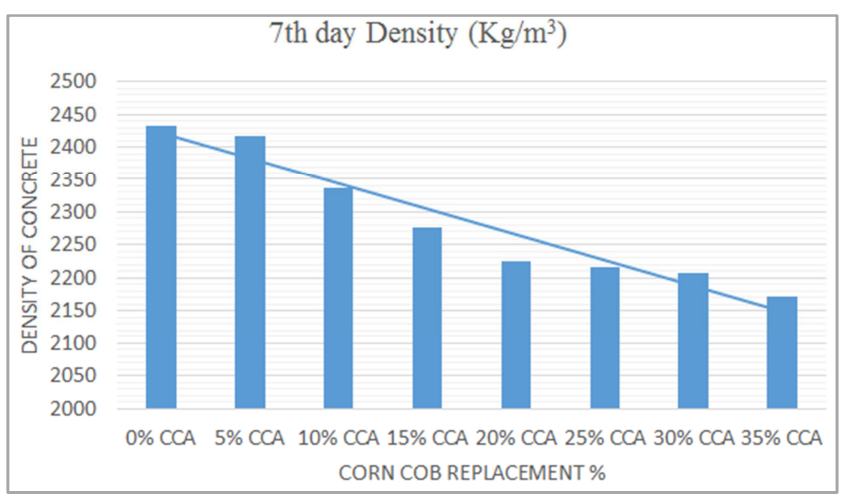

Figure 1. $7^{\text {th }}$ Day Density of Concrete.

After 28 day of curing, before samples were checked for compressive strength, mass of sample was measured and density is also decreasing when corn cob ash replacement increases as shown in figure 2 below.

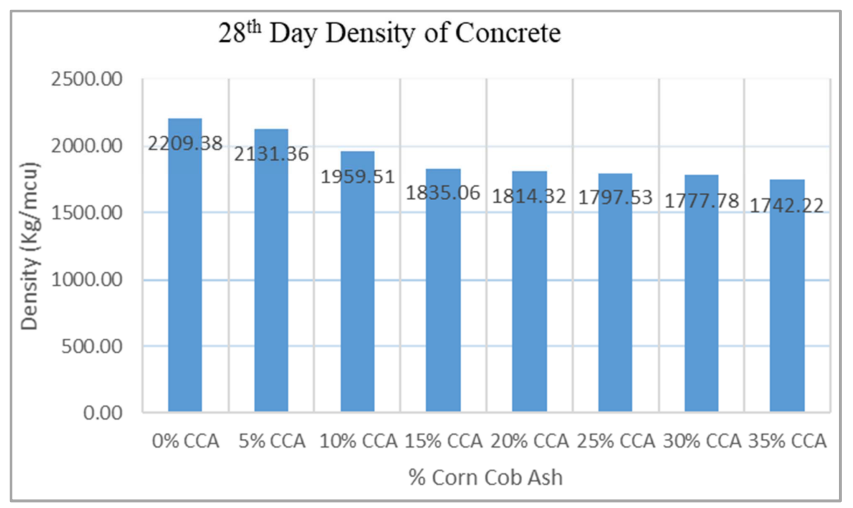

Figure 2. $28^{\text {th }}$ Day of Concrete Density.

According to NRMCA (2003) [15], structural light weight concrete has an in place density (Unit weight) $1440 \mathrm{Kg} / \mathrm{m}^{3}$ to $1840 \mathrm{Kg} / \mathrm{m}^{3}$. The result of this study indicates, replacing cement by $15 \%$ and above corn cob ash will make the concrete light weight.

\subsection{Compressive Strength}

In order to evaluate strength development in concrete containing various percentage of corn cob ash as replacement of cement, cube $(150 \mathrm{~mm} \mathrm{X} \mathrm{150mm} \mathrm{X} 150 \mathrm{~mm})$ was tested for compressive strength at 7 and 28 days. Generally, the result shows, compressive strength of concrete decreases as the amount of corncob ash replacement increases.

The seventh day compressive strength should be between 60 to $70 \%$, average $65 \%$ of the expected characteristic strength. The result of analysis shows; $20 \%$ replacement is possible which is above the acceptable limit, $16.25 \mathrm{MPa}$. However, if minimum requirement or $60 \%$ of strength is expected, $25 \%$ replacement is possible.

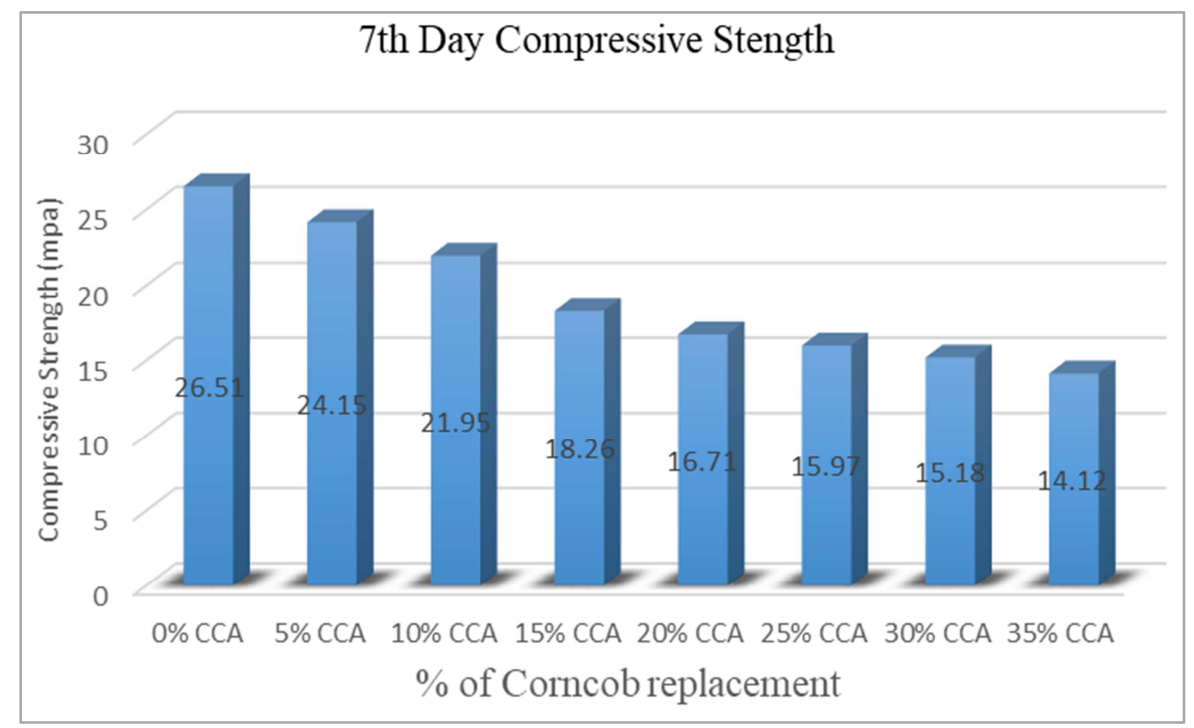

Figure 3. 7th Day Compressive Strength 
The most acceptable compressive strength test is $28^{\text {th }}$ day strength. It is expected to achieve $99 \%$ of the characteristics strength. The result of this study shows; it is possible only to replace corncob ash up to $15 \%$.

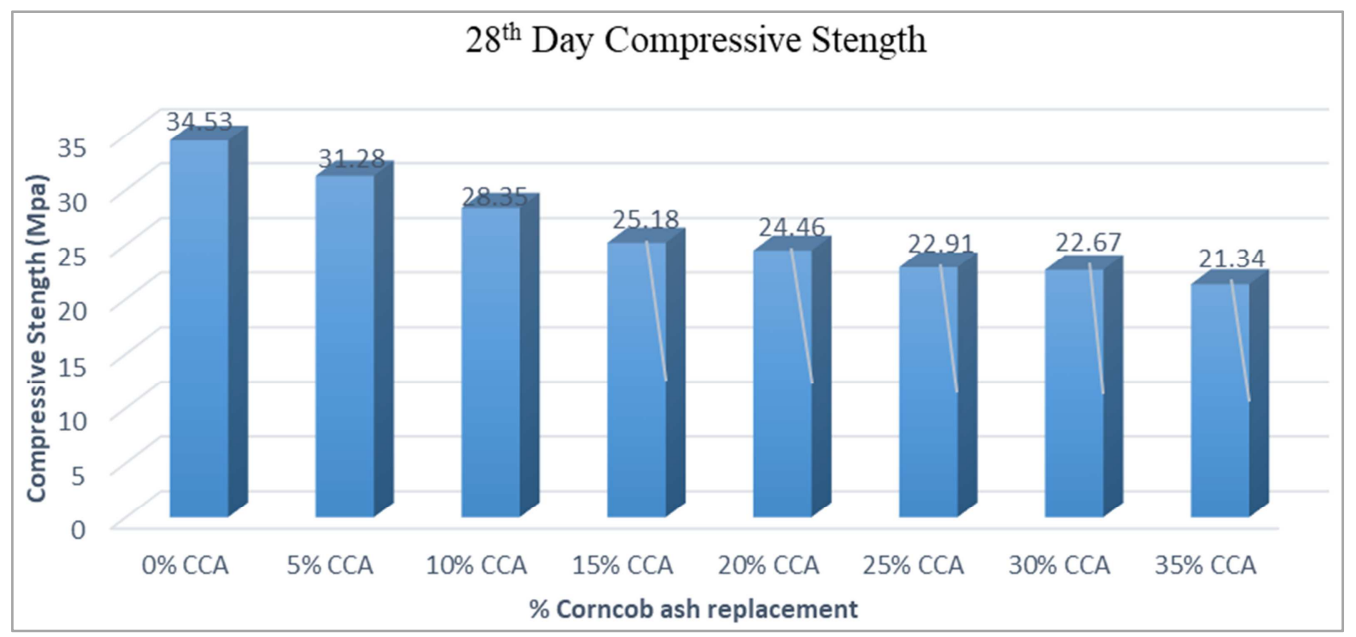

Figure 4. $28^{\text {th }}$ Day Compressive Strength.

\section{Conclusion}

The study result shows, using corn cob ash as cement replacement and producing light weight concrete is possible. Generally, as the replacing percentage of corn cob ash increased, the slump value, the unit weight and compressive strength of C-25 grade of concrete is slightly decreased.

Replacing of cement with corn cob ash up to $15 \%$ is acceptable with a compressive strength of 28th day which is $25.18 \mathrm{MPa}$ and is greater than $99 \%$ of the 28 th day by $1 \%$ increment. The slump value of $26.0 \mathrm{~mm}$ which is within the limit and the density of the concrete at the 28th day curing is $1834.07 \mathrm{~kg} / \mathrm{m}^{3}$, which is in the range of light weight concrete.

In order to make concretes produced by replacing corncob ash lighter in weight, some admixtures can be added to enhance the compressive strength and workability and hence corncob ash amount can be increased.

\section{References}

[1] J. Pinto et al., "Corn cob lightweight concrete for nonstructural applications," Constr. Build. Mater., vol. 34, pp. 346-351, 2012.

[2] A. Olaniyi and A. A. Umoh, "I NFLUENCE O F C URING M EDIA O N T HE C OMPRESSIVE S TRENGTH O F T ERMITE M OUND -L IME B LENDED C EMENT M ORTAR," Malaysian J. Civ. Eng., vol. 26, no. 3, pp. 349-365, 2014.

[3] M. Berry, D. Cross, and J. Stephens, "Changing the Environment: An Alternative 'Green' Concrete Produced without Portland Cement," in world of Coal Ash Conference, 2009.

[4] ACI Committee, Building Code Requirements for Structural Concrete (ACI 318-08). American Concrete Institute, 2008.
[5] S. W. Harrison, "A study of alternative building materials and technologies for housing in Bangalore, India," Constr. Build. Mater, vol. 9, no. 4, pp. 211-217, 1995.

[6] B. Getachew, T. Adugna, and S. Assefa, "INVESTIGATION ON THE EFFECT OF STORAGE TIME DUE TO MOISTURE ABSORPTION OF CEMENT ON THE PROPERTIES OF CONCRETE," Int. J. Dev. Res., vol. 08, no. 01, pp. 18558-18561, 2018.

[7] C. R. C. X. C. Qiao, B. R. Hg, M. Tyrer, C. S. Poon, "Production of lightweight concrete using incinerator bottom ash," Constr. Build. Mater., vol. 22, pp. 473-480, 2008.

[8] Y. E. Mark Nisnevich, Gregory Sirotin, Tuvia Schlesinger, "Radiological safety aspects of utilizing coal ashes for production of lightweight concrete," Fuel, vol. 87, pp. 16101616, 2008.

[9] B. J. Tay and W. Yip, "Sludge ash as lightweight concrete material," J. Environ. Eng., vol. 115, no. 1, pp. 56-64, 1989.

[10] K. D. Oluborode and I. O. Olofintuyi, "Strength Evaluation of Corn cob ash in a blended Portland cement," Int. J. Innov. Technol., vol. 4, no. 12, pp. 14-17, 2015.

[11] A. M. Neville, Properties of concrete, 5th ed. Trans-Atlantic Publications, Inc., 2011.

[12] Ministry of Urban Development Housing and Construction, Standard Technical Specifications for Building Works. Addis Ababa, 2014.

[13] American Society for Testing and Materials, "Standard Specification for Concrete Aggregates," in ASTM Standards, vol. 04, West Conshohocken, PA: ASTM International, 2001.

[14] American Society for Testing and Materials, "Standard Practice for Making and Curing Concrete Test Specimens in the," in ASTM Standards, vol. 04, Farmington, 2000, pp. 1-8.

[15] NRMCA, "Concrete in Practice," 2003. [Online]. Available: https://www.nrmca.org/aboutconcrete/cips/36p.pdf. [Accessed: 05-Feb-2019]. 